\section{Screening for congenital heart disease in high-risk population: Indications for fetal echocardiography}

Arsic Biljana ${ }^{1}$, Perovic Milan², Garalejic Eliana ${ }^{\mathbf{1}}$, Simic Aleksandra $^{2}$

${ }^{1}$ University Clinic for Gynecology and Obstetrics

"Narodni front", Belgrade, Serbia

${ }^{2}$ Hospital for Gynecology and Obstetrics, Clinical hospital Center "Zemun”- Belgrade, Belgrade, Serbia

\section{Abstract}

Prenatal diagnosis of congenital heart disease is crucial to optimal obstetric and neonatal care. In utero identification of heart anomalies allows a variety of treatment options to be considered, including delivery at an appropriate facility, termination of pregnancy, and in some cases in utero therapy. Specific indications and risks have been classified and patients considered at high risk have been offered detailed fetal echocardiography, commonly at a center with appropriate expertise and facilities. However, most children are born to mothers who have no known risk features during pregnancy. Screening in the low-risk population has been reported to have lower accuracy rates then in high-risk population. The most common indication for performing a fetal echocardiogram is a prior family history of congenital heart disease. A number of drugs have been implicated as causes of various malformations, including heart anomalies. Therefore, their use during pregnancy is considered as indication for echocardiography. Several maternal conditions also carry an inherited risk to the fetus and their presence is also indication for this diagnostic procedure. The incidence of congenital heart disease is increased fivefold among infants of diabetic mothers, whereas phenylketonuria has reported risk of 12 to $16 \%$. Chromosomal anomalies, extracardiac malformations and monozigotic twins are also indications for fetal echocardiography.

Key words: congenital heart disease, fetal echocardiography, indications

Prenatal diagnosis of congenital heart disease (CHD) is crucial to optimal obstetric and neonatal care. In utero identification of heart anomalies allows a variety of treatment options to be considered,

\section{Skrining kongenitalne srčane bolesti u visoko-rizičnoj populaciji: Indikacije za fetalnu ehokardiografiju}

Arsić Biljana ${ }^{1}$, Perović Milan ${ }^{2}$, Garalejić Eliana ${ }^{1}$, Simić Aleksandra $^{2}$

${ }^{1}$ Univerzitetska Klinika za ginekologiju i akušerstvo

„Narodni front”, Beograd, Srbija

2 Bolnica za ginekologiju i akušerstvo, Kliničkobolnički centar „Zemun”- Beograd, Beograd, Srbija

\section{Apstrakt}

Prenatalna dijagnoza kongenitalne srčane bolesti je krucijalna za optimalnu obstetričku i neonatalnu negu. Njeno otkrivanje dok je plod još u majčinoj utrobi, omogućava razmatranje širokog spektra terapijskih opcija, uključujući porođaj u odgovarajućem centru, prekid trudnoće, a u nekim slučajevima in utero terapiju. Danas je preporuka da se u slučaju postojanja specifičnih indikacija i faktora rizika za kongenitalnu srčanu bolest pacijenti šalju na fetalnu ehokardiografiju, najčešće $u$ centre sa odgovarajućim dijagnostičkim aparatima i ekspertizom. Ipak, najveći broj dece sa urođenim srčanim manama rođen je od strane majki koje tokom trudnoće nisu imale faktore rizika za kongenitalnu srčanu bolest. Skrining nisko-rizične populacije ima znatno nižu dijagnostičku pouzdanost od skrininga u populaciji visoko-rizičnih žena. Najčešća indikacija za fetalnu ehokardiografiju je podatak o kongenitalnoj srčanoj bolesti kod nekog od članova uže porodice. Određeni broj lekova i supstanci povezan je sa pojavom različitih srčanih anomalija, te je njihovo korišćenje u trudnoći jedna od indikacija. Neka oboljenja majke nose hereditarne rizike kongenitalnih srčanih anomalija fetusa i njihovo postojanje je razlog za upućivanje na ovu dijagnostičku metodu. Incidenca urođenih srčanih mana je pet puta veća kod dece dijabetičnih majki, dok fenilketonurija nosi rizik kongenitalne srčane bolesti 12 do $16 \%$. U indikacije spadaju i fetalne hromozomske anomalije i ekstrakardijalne malformacije, kao i monozigotni blizanci.

Ključne reči: kongenitalna srčana bolest, fetalna ehokardiografija, indikacije

Prenatalna dijagnoza kongenitalne srčane bolesti (KSB) je krucijalna za optimalnu obstetričku i 
including delivery at an appropriate facility, termination of pregnancy, and in some cases in utero therapy ${ }^{1}$. Unfortunately, cardiac anomalies are the most frequently overlooked malformations during prenatal ultrasound evaluation. This has profound medical, psychological and medicolegal consequences ${ }^{2}$. Recommendations on indications for fetal echocardiography are closely linked to the recognition of possible etiologic factors and risk groups in respect of CHD. Three main etiologic groups have been identified on the basis of empirical, animal experimental and genetic data ${ }^{3}$.

In recent years, efforts have predominantly focused on developing screening programs for prenatal diagnosis of congenital heart anomalies. Specific indications and risks have been classified and patients considered at high risk have been offered detailed fetal echocardiography, commonly at a center with appropriate expertise and facilities. However, most children are born to mothers who have no known risk features during pregnancy. Screening in the low-risk population has been reported to have lower accuracy rates then in high-risk population ${ }^{4}$. The impact of these screening programs on the mortality and morbidity with children with prenatally diagnosed cardiac anomalies and of the general population has been evaluated with different results. Fetuses with lesions that require intervention early in the neonatal period might especially benefit from closer care and the planning of delivery. In addition, the possibility of intrauterine cardiac intervention, which is established for anti-arrythmic treatment, might further improve fetal outcome ${ }^{2}$.

\section{Prior family history of congenital heart disease}

The most common indication for performing a fetal echocardiogram is a prior family history of congenital heart disease. In the past most congenital heart defects was considered sporadic or mulitfactorial but many defects have been found to have an underlying genetic basis ${ }^{\mathbf{5 , 6}}$. There are inheritable syndromes which often follow autosomal recessive or dominant inheritance patterns. Some families with heterotaxy syndrome appear to have an X-linked recessive pattern of inheritance. Holt-Oram syndrome is autosomal dominant with family members most commonly having atrial septal defects and upper limb abnormalities. In most families we do not know what the recurrence risks are but use estimates based on previous neonatalnu negu. Njeno otkrivanje dok je plod još u majčinoj utrobi, omogućava razmatranje širokog spektra terapijskih opcija, uključujući porođaj u odgovarajućem centru, prekid trudnoće, a u nekim slučajevima in utero terapiju ${ }^{1}$. Nažalost, srčane anomalije su najčešće prenatalno nedijagnostikovane malformacije. Ovo ima duboke medicinske, psihološke i medikolegalne posledice ${ }^{2}$. Indikacije za fetalnu ehokardiografiju su nastale nakon prepoznavanja mogućih etioloških faktora i faktora rizika za KSB. Tri glavne etiološke grupe identifikovane su na bazi empirijskih, animalnih eksperimentalnih istraživanja i genetskih podataka ${ }^{3}$.

Poslednjih decenija osmišljeni su skrining programi za prenatalnu dijagnozu kongenitalnih srčanih anomalija. Danas je preporuka da se u slučaju postojanja specifičnih indikacija i faktora rizika za KSB pacijenti šalju na detaljnu fetalnu ehokardiografiju, najčešće u centre sa odgovarajućim dijagnostičkim aparatima i ekspertizom. Ipak, najveći broj dece sa urođenim srčanim manama rođen je od strane majki koje tokom trudnoće nisu imale prepoznate faktore rizika za kongenitalnu srčanu bolest. Skrining nisko-rizične populacije ima znatno nižu dijagnostičku pouzdanost od skrininga u populaciji visoko-rizičnih žena ${ }^{4}$. Analize uticaja skrining programa na mortalitet i morbiditet dece u opštoj populaciji i u populaciji dece sa prenatalno dijagnostikovanom KSB su dale različite rezultate. Fetusi sa onom vrstom KSB koja zahteva intervenciju u ranom neonatalnom periodu će imati koristi od učestalijeg i detaljnijeg praćenja i tretmana, kao i planiranja vremena i mesta porođaja. Ovo je važno u slučaju intrauterinog kardiološkog antiaritmijskog tretmana, a koji poboljšava perinatalni ishod ${ }^{2}$.

\section{Postojanje kongenitalne srčane bolesti u porodici}

Najčešća indikacija za fetalnu ehokardiografiju je podatak o KSB u porodičnoj anamnezi. U prošlosti je većina kongenitalnih srčanih defekata smatrana sporadičnom ili multifaktorijalno izazvanom pojavom. Ipak, danas se zna da mnogi defekti imaju u pozadini genetsku osnovu ${ }^{\mathbf{5 , 6}}$. Neki nasledni sindromi često imaju autozomalno-recesivne ili dominantno nasledne obrasce nasleđivanja. Porodice sa heterotaksičnim sidromom često imaju hromozom $\mathrm{X}$-zavisne recesivne šeme nasleđivanja. Holt-Oram 
studies. The recurrence risk with one previous child with congenital heart defects is 2 to $5 \%$ and increases to 3 to $10 \%$ with two children. Mothers with congenital heart defects have a higher recurrence risk of 5 to $10 \%{ }^{6}$. There is less information regarding the recurrence risk in fathers. Certain types of defects have higher recurrence risks. The highest risk is for left heart obstructive defects such as hypoplastic left heart syndrome, aortic stenosis and coarctation of the aorta, with recurrence rates up to 10 to $15 \%$. Septal defects and conotruncal anomalies have a moderate recurrence risk of 2 to $5 \%$. Transposition of the great arteries and single ventricle anomalies have lower recurrences of less than $2 \%$.

\section{Teratogens}

A number of drugs have been implicated as causes of various malformations, including heart anomalies. Exposure to known cardiac teratogens in the first 6-8 weeks of pregnancy also increases the fetus' risk of having a heart defect. In this context, alcohol, antiepileptics, lithium and retinoic acid are the most important drugs. Exposure of the fetus to alcohol, especially if the fetal alcohol syndrome develops, can be associated with congenital heart defects in up to $25 \%{ }^{7,8}$. The most common defects are a patent ductus arteriosus or septal defects. Isotretinoin (Retinoic acid) is also very teratogenic with many exposed fetuses developing congenital heart defects. The most common defects are conotruncal and great artery abnormalities, such as transposition of the great arteries, tetralogy of Fallot, double outlet right ventricle, truncus arteriosus and interrupted aortic arch. Historically, exposure to thalidomide had a 5 to $10 \%$ incidence of cardiac defects especially tetralogy of Fallot, truncus arteriosus and septal defects 9 . Many of the anticonvulsants have been implicated as causes of congenital heart defects. Valproic acid has the strongest evidence for teratogenic effects, with phenytoin and trimethadione also implicated ${ }^{\mathbf{1 0}, \mathbf{1 1}}$. The cardiac defects most frequently seen are patent ductus arteriosus, aortic stenosis, ventricular septal defect, tetralogy of Fallot, coarctation of the aorta and transposition of the great arteries. The teratogenic effects of lithium have recently been questioned ${ }^{12,13}$. Probably the overall incidence of congenital heart disease is not increased with lithium exposure but when congenital heart disease is found it usually is Ebstein's sindrom se nasleđuje autozomno-dominantno, a u ovakvim porodicama najčešće su prisutni atrioseptalni defekti i defekti gornjih ekstremiteta. Tačan rizik javljanja KSB u potomaka porodica gde je ova bolest prisutna nije tačno poznat. Ipak, on se može proceniti na osnovu do sada izvedenih epidemioloških studija. U roditelja čije jedno dete ima KSB, rizik njenog javljanja kod sledećeg deteta je 2 do $5 \%$, a rizik u slučaju dvoje afektirane dece raste i do 3 do $10 \%$. Žena sa KSB nosi rizik od 5 do $10 \%$ da rodi dete sa kongenitalnim srčanim defektom ${ }^{6}$. Postoji mali broj literaturnih podataka vezanih za rizike ukoliko je otac nosilac KSB. Pojedini tipovi kongenitalnih srčanih mana nose visok rizik ispoljavanja u potomstvu. Najveći je kod obstruktivnih defekata levog srca, kao što su sindrom hipoplastičnog levog srca, aortna stenoza i koarktacija aorte, a iznosi 10 do $15 \%$. Septalni defekti i konotrunkalne anomalije nose umeren rizik pojave u narednim generacijama od 2 do 5\%. Transpozicija velikih arterija i jednokomorne anomalije imaju nizak rizik ispoljavanja u potomstvu od $2 \%$.

\section{Teratogeni}

Određeni broj lekova i supstanci je povezan sa pojavom različitih malformacija, uključujući i srčane anomalije. Korišćenje kardiogenih teratogena u prvih 6 do 8 nedelja trudnoće povećava rizik pojave srčanih defekata fetusa. U ovom kontekstu, najznačajniji su alkohol, a od lekova antiepileptici, litijum i retinoična kiselina. Izlaganje fetusa alkoholu, naročito ukoliko dođe do razvijanja fetalnog alkoholnog sindroma, može biti povezano sa kongenitalnim srčanim defektima i u do $25 \%$ slučajeva ${ }^{7,8}$. Najčešći alkoholom uzrokovani defekti su septalni i patentni duktus arteriozus. Izoretinoin (retinoična kiselina) je veoma teratogena i veliki broj fetusa izloženih njenom uticaju je razvio kongenitalne srčane defekte. Najčešći su konotrunkalne i anomalije velikih arterija, kao što su transpozicija velikih arterija, tetralogija Fallot, double outlet right ventricle, trunkus arteriozus i prekinuti aortni luk. Dok nisu otkriveni teratogeni efekti thalidomida, ovaj lek je često korišćen i od strane trudnica. To je za posledicu imalo incidencu kongenitalnih srčanih defekata od 5 to $10 \%$, a najčešće anomalije bile su tetralogija Fallot, trunkus arteriozus i septalni defekti ${ }^{9}$. Veliki broj antikonvulzanata može uzrokovati KSB. Valproična kiselina ima najjači teratogeni efekat, a 
anomaly, an otherwise rare cardiac defect. With the exception of daunorubicin which appears to cause myocardial necrosis, the antineoplastic drugs have not been associated with congenital heart disease ${ }^{\mathbf{1 4}}$. Other drugs, such as the amphetamines, tranquilizers and cocaine, remain controversial. The specific risk of occurence varies with the lenght and types of exposure as well as with the specific substance involved.

\section{Maternal disease}

Several maternal conditions also carry an inherited risk to the fetus. The incidence of CHD is increased fivefold among infants of diabetic mothers, whereas phenylketonuria has reported risk of 12 to $16 \%$.

\section{Insulin-requiring Diabetes mellitus}

The incidence of congenital heart defects in infants of diabetic mothers was about $5 \%$ but with better diabetic control the incidence has fallen. Structural defects most commonly seen in infants of diabetic mothers are ventricular septal defects, transposition of the great arteries, coarctation of the aorta and other conotruncal anomalies like double outlet right ventricle and truncus arteriosus. Hypertrophic cardiomyopathy is seen in insulin dependent and gestational diabetics, usually in the last months of pregnancy ${ }^{15}$. Good metabolic control of maternal blood sugar respectively, periconceptionaly and during the first 8 weeks of pregnancy might decrease the risk of the affected mothers to near the level of the normal population ${ }^{\mathbf{1 6}}$.

\section{Collagen Vascular Disease}

Complete heart block in the fetus is associated with maternal collagen vascular disease (systemic lupus erythematosus). Women with either SSA or SSB (anti-Ro or anti-La) antibodies are at risk for the fetus developing congenital heart block and myocarditis. The women often do not have collagen vascular disease. Congenital heart block in a fetus with no structural heart disease is almost always associated with one or both of these antibodies and they should be looked for. The antibodies are usually gone by 3 months of age but the damage to the conduction system has been done. If there are maternal autoantibodies SSA or SSB, wheather they are ill or healthy women, repetitive echocardiographic examinations of the fetal heart should be performed in the second and third trimesters for early detection of autoantibody-induced fetal heart block and cardiomyopathy. Perinatal slede phenytoin i trimethadion ${ }^{\mathbf{1 0}, 11}$. Najčešći srčani defekti koji su posledica upotrebe antikonvulzanata su patentni duktus arteriozus, aortna stenoza, ventrikularni septalni defekti, tetralogija Fallot, koarktacija aorte i transpozicija velikih arterija. Teratogeni efekti litijuma se od skora preispituju ${ }^{\mathbf{1 2} 13}$. Najverovatnije se sveukupna incidenca KSB ne povećava u slučaju korišćenja litijuma, ali se Ebštajnova anomalija, kao veoma retka, često javlja u fetusa čije su majke koristile litijum tokom trudnoće. Sa izuzetkom daunorubicina koji izaziva miokardijalnu nekrozu fetusa, drugi antineoplastični lekovi nisu povezani sa $\mathrm{KSB}^{\mathbf{1 4}}$. Teratogeno dejstvo ostalih supstanci i lekova, kao što su amfetamini, trankilizeri i kokain i dalje ostaje kontroverzno. Specifičan rizik pojave KSB u fetusa majki koje su koristile teratogene u trudnoći može se proceniti samo uzimajući u obzir vrstu teratogena i dužinu i vreme uzimanja teratogenih supstanci u trudnoći.

\section{Bolesti majke}

Nekoliko oboljenja majki nose hereditarne rizike kongenitalnih fetalnih srčanih anomalija. Incidenca KSB je pet puta veća u dece dijabetičnih majki, dok fenilketonurija nosi rizik KSB od 12 do $16 \%$.

\section{Inzulin-zavisni dijabetes melitus}

Incidenca kongenitalnih srčanih defekata u dece dijabetičnih majki iznosi oko $5 \%$, ali što je bolja metabolička kontrola bolesti to je procenat ovih anomalija niži. Strukturni defekti koji se najčešće viđaju u dece dijabetičnih majki su ventrikularni septalni defekti, transpozicija velikih arterija, koarktacija aorte i druge konotrunkalne anomalije, kao što su double outlet right ventricle and trunkus arteriozus. Hipertrofična kardiomiopatija se viđa u inzulin-zavisnoj bolesti, ali uglavnom poslednjih meseci trudnoće ${ }^{15}$. Dobra metabolička kontrola maternalne glikemije neposredno pre koncepcije i tokom prvih 8 nedelja trudnoće mogu smanjiti rizik rođenja deteta sa KSB na onaj nivo koji važi za zdravu populaciju ${ }^{\mathbf{1 6}}$.

\section{Kolagena vaskularna bolest}

Kompletni srčani blok može se javiti u fetusa majki sa kolagenom vaskularnom bolešću (sistemski lupus eritematozus). Osobe bilo sa SSA ili SSB (anti-Ro ili anti-La) antitelima imaju povećan rizik da im fetusi razviju kongenitalni srčani blok i miokarditis. Nekad i pored prisutnih antitela, trudnice nemaju razvijenu kolagenu vaskularnu bolest. Kongenitalni srčani blok fetusa bez strukturnih srčanih defekata skoro uvek je povezan sa prisustvom ovih antitela. 
mortality for isolated congenital heart block is 10 to $15 \%{ }^{(17)}$. Recurrence risk in subsequent pregnancies has recently been reported at $8 \% \mathbf{1 8}$.

\section{Phenylketonuria}

Like diabetes, phenylketonuria adversely affects the fetus when the mother is not adequately treated ${ }^{\mathbf{1 9}}$. Treatment is with a low phenylalanine diet to prevent mental retardation in the mother and congenital heart disease, microcephaly, intrauterine growth retardation and mental retardation in the infant. Good dietary control results in a decreased incidence of malformations but should be started before conception keeping phenylalanine levels less than 400-600 $\mu \mathrm{mol} / \mathrm{L}$. Structural defects seen most commonly with phenylketonuria are ventricular septal defects, coarctation of the aorta, hypoplastic left heart syndrome and tetralogy of Fallot ${ }^{\mathbf{1 9}}$.

Maternal infection

Maternal infection has also been reported to be associated with heart defects in fetus. Some viral intrauterine infections may be associated with an elevated risk of fetal cardiac lesions. Of the infectious agents, rubella is the only one associated with structural defects, especially as part of the congenital rubella syndrome ${ }^{20}$. The defects most commonly seen are patent ductus arteriosus, pulmonary stenosis, and septal defects. The effect of parvovirus on the heart has been mainly secondary to anemia and the fetal hydrops that develops but the parvovirus can also affect the myocardial cell itself ${ }^{21,22}$. Other viruses, such as Coxsackie, may affect the heart prenatally as well2.

\section{Documented fetal anomaly}

\section{Extracardiac malformations}

Extracardiac malformations frequently associated with cardiac anomaly ${ }^{9}$. Fetuses with diagnosed extracardiac anomalies constitute another major group of patients in whom fetal echocardiography is warranted, as the detection of cardiac anomaly fundamentally affects the prognosis and might influence perinatal care strategies ${ }^{2}$. Some extracardiac malformations carry a low risk of associated CHD, whereas for the others the risk is high.

Extracardiac malformations are present in 25 to $45 \%$ of children with congenital heart disease ${ }^{9}$. Table 1 reviews the extracardiac malformations most commonly associated with congenital heart disease ${ }^{2}$.
Zato se na njih mora misliti ukoliko je on prisutan. Antitela obično nestaju u trećem mesecu života, ali je oštećenje sprovodnog sistema srca već načinjeno. Prisustvo maternalnih SSA ili SSB antitela, bez obzira da li se radi o zdravim ili bolesnim ženama, obavezuje na ponavljanje ehokardiografskih pregleda fetusa tokom drugog i trećeg trimestra, a u cilju rane detekcije autoantitelima-izazvanim srčanim blokom i kardiomiopatije fetusa. Perinatalni mortalitet u slučajevima izolovanog kongenitalnog srčanog bloka je 10 do $15 \%{ }^{17}$. Rizik ponovne pojave kongenitalnog srčanog bloka fetusa u narednim trudnoćama iznosi oko $8 \% \mathbf{~} \mathbf{1 8}$.

\section{Phenylketonuria}

Kao i u slučaju dijabeta, neželjeni ishodi i posledice prisutni su u fetusa neadekvatno lečenih obolelih majki ${ }^{19}$. Terapija dijetom sa niskim dozama phenylalanina u cilju prevencije mentalne retardacije majke i kongenitalne srčane bolesti fetusa, mikrocefalije, intrauterinog zastoja rasta i mentalne retardacije deteta su obligatorni. Dobra dijetetska kontrola smanjuje incidencu malformacija ploda, ali pod uslovom da je započeta prekoncepcionalno i ukoliko održava nivoe phenylalanina ispod 400-600 $\mu \mathrm{mol} / \mathrm{L}$. Najčešći tip strukturnih srčanih defekata dece majki obolelih od phenylketonuria su ventrikularni septalni defekti, koarktacija aorte, sindrom hipoplastičnog levog srca i tetralogija ${ }^{19}$.

\section{Maternana infekcija}

Neke infekcije trudnice su povezane za srčanim defektima fetusa. Pojedine virusne infekcije nose rizik nastanka fetalnih srčanih lezija. Od svih infektivnih agenasa, rubella je jedina kod koje je dokazano da izazva strukturne defekte fetalnog srca, naročito ako njeno prisustvo dovede do ispoljavanja kongenitalnog rubela sindroma ${ }^{20}$. Infekcija rubelom najčešće je povezana sa patentnim duktus arteriozusom, stenozom pulmonarne arterije i septalnim defektima. Efekti parvovirusne infekcije na fetalno srce su primarno posledica fetalne anemije i hidropsa koji nastaju kao direktna posledica ovog virusa, ali i ona sama može oštetiti i miokardijalne ćelije ${ }^{21,22}$. Drugi virusi, kao što je Coxsackie, mogu štetno delovati na fetalno srce ${ }^{2}$.

\section{Dokumentovana fetalna anomalija}

\section{Ekstrakardijalne malformacije}

Ekstrakardijalne malformacije su često povezane sa srčanim anomalijama9 ${ }^{9}$. Fetusi sa ekstrakardijalnim 
Table 1.

\begin{tabular}{|c|c|}
\hline \multirow{2}{*}{ Central nervous system } & $\begin{array}{c}\text { Hydrocephalus } \\
\text { microcephalus } \\
\text { agenesis of corpus } \\
\text { callosum } \\
\text { encephalocoele } \\
\text { Dandy-Wolker } \\
\text { malformation }\end{array}$ \\
\hline Mediastinum & $\begin{array}{c}\text { diaphragmatic hernia } \\
\text { tracheoesophagal fistula }\end{array}$ \\
\hline Gastrointestinal & $\begin{array}{c}\text { duodenal atresia } \\
\text { abnormal situs visceralis } \\
\text { anorectal anomalies }\end{array}$ \\
\hline Abdominal wall & $\begin{array}{c}\text { Omphalocele } \\
\text { ectopia cordis }\end{array}$ \\
\hline Genitourinary & $\begin{array}{c}\text { Hydronephrosis } \\
\text { renal agenesis } \\
\text { horseshoe kidney }\end{array}$ \\
\hline Vascular & single umbilical artery \\
& persistent right umbilical \\
& vein \\
\hline Syndromes & DiGeorge \\
& Holt-Oram \\
& Marfan \\
& Noonan \\
\hline
\end{tabular}

Extracardiac malformations are more common in children with atrioventricular septal defects, other septal defects, heterotaxy syndromes and conotruncal defects; less common in left heart defects and uncommon in transposition of the great arteries. Increased nuchal translucency without chromosomal abnormalities is associated with cardiac defects, especially narrowing of the aorta ${ }^{23}$.

\section{Chromosomal anomalies}

Fetuses with a chromosomal abnormality frequently have congenital heart defects (Table 2$)^{2}$. Fetuses with congenital heart disease also have a significant risk of having a chromosomal abnormality ${ }^{24}$. Therefore, complete cardiac examination should be performed in all fetuses with anomalies detected by karyotyping and vice versa ${ }^{2}$. A high intrauterine mortality rate is reported in those fetuses prenatally detected heart disease and associated chromosomal pathology ${ }^{2}$. Consequently, the frequency of an associated abnormal caryotype is far higher in prenatal studies then in liveborn infants. In live born infants with congenital heart disease the incidence of chromosomal abnormalities was $12.5 \%$. In prenatal series the incidence varies from 15 to $38 \%$ depending on gestational age 25 . The detection of a cardiac defect alone is often enough to recommend genetic testing and anomalijama čine drugu veliku grupu pacijenata kod kojih je obavezna fetalna ehokardiografija, s obzirom da dijagnoza srčanih anomalija fundamentalno utiče na prognozu, a time i na perinatalnu strategi$\mathrm{ju}^{2}$. Neke vrste ekstrakardijalnih anomalija nose nizak rizik istovremenog postojanja KSB, dok drugi tipovi ekstrakardijalnih malformacija nose visok rizik koincidencije sa kongenitanim srčanim anomalijama. Ekstrakardijalne malformacije prisutne su u 25 do $45 \%$ dece sa KSB ${ }^{9}$. Tabela broj 1 daje prikaz onih ekstrakardijalnih malformacija koje su najčešće povezane sa $\mathrm{KSB}^{2}$.

Tabela 1.

\begin{tabular}{|c|c|}
\hline Centralni nervni sistem & $\begin{array}{c}\text { Hidrocefalus } \\
\text { mikrocefalija } \\
\text { agenezija korpus } \\
\text { kalozuma } \\
\text { encefalokela } \\
\text { Dandy-Wolker } \\
\text { malformacija }\end{array}$ \\
\hline Medijastinum & $\begin{array}{c}\text { Dijafragmatična hernija } \\
\text { Traheoezofagealna } \\
\text { fistula }\end{array}$ \\
\hline Gastrointestinalni trakt & $\begin{array}{c}\text { duodenalna atrezijia } \\
\text { abnormalni visceralni } \\
\text { situs } \\
\text { anorektalne anomalije }\end{array}$ \\
\hline Trbušni zid & $\begin{array}{c}\text { Omfalocela } \\
\text { Ektopija srca }\end{array}$ \\
\hline Genitourinarni trakt & $\begin{array}{c}\text { Hidronefroza } \\
\text { agenezija bubrega } \\
\text { potkovičasti bubreg }\end{array}$ \\
\hline Vaskularne anomalije & $\begin{array}{c}\text { single umbilical artery } \\
\text { perzistentna desna } \\
\text { umbilikalna vena }\end{array}$ \\
\hline Sindromi & $\begin{array}{c}\text { DiGeorge } \\
\text { Holt-Oram } \\
\text { Marfan } \\
\text { Noonan } \\
\end{array}$ \\
\hline
\end{tabular}

Ektrakardijalne malformacije su česte u dece sa atrioventrikularnim i ostalim septalnim defektima, heterotaksičnim sindromom i konotrunkalnim anomalijama; ređe u levostranim srčanim defektima, dok su veoma retke u dece sa transpozicijom velikih krvnih sudova. Zadebljanje nuhalne translucence koje nije posledica hromozomskih abnormalnosti povezano je sa srčanim defektima, naročito sa suženjem aorte ${ }^{\mathbf{2 3}}$.

\section{Hromozomske anomalije}

Fetusi sa hromozomskim anomalijama često imaju i kongenitalne srčane defekte (Tabela 2) ${ }^{2}$. Takođe, fetusi sa KSB imaju visok rizik hromozomskih 
if any other abnormality is present testing would be strongly recommended ${ }^{2}$.

Table 2. Chromosomal abnormalities associated with CHD

\begin{tabular}{llc}
\hline Karyotype & $\begin{array}{l}\text { Associated } \\
\text { heart defects }\end{array}$ & Risk (\%) \\
\hline \multirow{2}{*}{ Trisomy 21 } & AVSD, VSD, & $40-50$ \\
& ASD, ToF, CoA & \\
& VSD, ToF, & \\
Trisomy 18 & DORV, HLH & \\
Trisomy 13 & VSD, ASD, & 99 \\
Monosomy & HLH, ToF & 90 \\
22q11 & Conotruncal & $85-95$ \\
(CATCH 22) & defects: & \\
& VSD, ToF, & \\
\hline
\end{tabular}

ASD, atrial septal defect; AVSD, atrioventricular septal defect; CoA, coartaction of aorta; DORV, double outlet right ventricle; TAC, truncus arteriosus communis; ToF, tetralogy of Fallot; VSD, ventricular septal defect.

\section{Twins}

Twins are not a malformation but monozygotic twins do have twice the incidence of congenital heart disease seen in dizygotic twins and the concordance rate is higher, ${ }^{\mathbf{9} 26}$. In conjoined twins, those with thoracopagus or thoraco-omphalopagus have a $75 \%$ incidence of congenital heart disease usually involving shared structures between the two hearts. In most of the others the pericardium is shared. Even in omphalopagus, congenital heart disease is found in at least one twin in 25\% ${ }^{\mathbf{9}, 26}$.

\section{Arrhythmias}

Fetal echocardiography should be preformed in all cases of fetal arrhythmia, not only for differentiation, but also for exclusion of a cardiac anomaly which may be present in 30-50\% of cases with complete atrioventricular block and in 2-5\% of cases with extrasystoles and tachyarrhythmias ${ }^{2}$. The most frequent type of fetal arrhythmia is premature atrial and ventricular contractions, that have little clinical significance and are not associated with an increased risk of structural abnormalities. Tachycardias frequently cause in utero heart failure but are rarely associated with structural anomalies. Conversely, $50 \%$ of fetuses with complete atrioventricular block have cardiac malformations, mostly atrioventricular septal defects or corrected transposition of the great arteries ${ }^{27}$.

Non-immune fetal hydrops abnormalnosti ${ }^{24}$. Zato je fetalna ehokardiografija neophodna kod svih fetusa sa detektovanim anomalijama posredstvom kariotipa i obrnuto ${ }^{2}$. Visoke stope intrauterinog mortaliteta su prisutne $\mathrm{u}$ fetusa kod kojih je prenatalno dijagnostikovana KSB bila udružena sa hromozomskom patologijom² ${ }^{2}$. Konsekventno, učestalost abnormalnog kariotipa udruženog sa KSB je daleko veća u prenatalnim studijama nego u novorođene dece. U živorođene dece sa KSB, incidenca hromozomskih abnormalnosti je oko $12.5 \%$. U prenatalnim serijama, incidenca varira od 15 do $38 \%$, a u zavisnosti od gestacione starosti ${ }^{25}$. Detekcija samo srčanog defekta u fetusa je često dovoljna da bi se predložilo genetsko testiranje dok bi se u slučaju koegzistencije neke druge abnormalnosti, genetsko testiranje snažno preporučilo ${ }^{2}$.

Tabela 2. Hromozomske abnormalnosti povezane sa KSB

\begin{tabular}{llc}
\hline Kariotip & $\begin{array}{l}\text { Udruženi srčani } \\
\text { defekti }\end{array}$ & Rizik (\%) \\
\hline Trizomija 21 & $\begin{array}{l}\text { AVSD, VSD, } \\
\text { ASD, ToF, CoA }\end{array}$ & $40-50$ \\
& $\begin{array}{l}\text { VSD, ToF, } \\
\text { Trizomija 18 }\end{array}$ & $\begin{array}{l}\text { DORV, HLH } \\
\text { VSD, ASD, }\end{array}$ \\
Trizomija 13 & HLH, ToF & 99 \\
Monozomija & Konotrunkalni & 90 \\
22q11 & defekti: & $85-95$ \\
(CATCH 22) & VSD, ToF, & \\
& DORV, TAC & \\
\hline
\end{tabular}

ASD, atrijalni septalni defekti; AVSD,

atrioventrikularni septalni defekti; CoA, koarktacija aorte; DORV, double outlet right ventricle; TAC, truncus arteriosus communis; ToF, tetralogija Fallot; VSD, ventrikularni septalni defekt.

\section{Blizanci}

Iako blizance nikako ne možemo smatrati malformacijom, oni su svrstani u ovu grupu jer monozigotni gemeli imaju dva puta veću incidencu kongenitalne srčane bolesti u odnosu na dizigotne blizance, ${ }^{\mathbf{9} 6}$. U sijamskih blizanaca sa thoracopagus-om ili thoraco-omphalopagus-om incidenca KSB je $75 \%$ i obično je vezana za zajedničke strukture koje dele njihova dva srca. U većini preostalih slučajeva, perikardijum je zajednički. Čak i u omphalopagus-u, KSB se javlja u jednom od ova dva blizanca u najmanje $25 \%$ slučajeva ${ }^{9}, 26$.

\section{Aritmije}

U svim slučajevima fetalnih aritmija potrebno je uraditi fetalnu ehokardiografiju, ne samo zbog 
The identification of non-immune hydrops fetalis is also considered an indication for fetal echocardiography. In some cases it may reflects structural heart disease, whereas in others is the result of an aryth$\mathrm{mia}^{\mathbf{2 8}}$. Non-immune fetal hydrops is secondary to a cardiac abnormality in $25 \%$ of cases ${ }^{29}$. Two-thirds of the cardiac cases are due to arrhythmias and onethird due to structural heart disease. Occasionally both an arrhythmia and structural heart disease can be present such as an atrioventricular septal defect with heart block, or Ebstein's anomaly with atrial flutter. The arrhythmias, can be tachyarrhythmias, such as supraventricular tachycardia or atrial flutter, or bradyarrhythmias, such as heart block. The structural anomalies most commonly associated with fetal hydrops are: 1) valve insufficiency, particularly Ebstein's anomaly and other tricuspid valve abnormalities, but also absent pulmonary valve syndrome and atrioventricular septal defect, and 2) outflow obstructions, particularly hypoplastic right or left heart syndromes, when associated with tricuspid valve insufficiency. The presence of fetal hydrops with either arrhythmia or structural heart disease worsens the prognosis. In particular, structural heart disease and complete heart block have an ominous prognosis when associated with hydrops with exceedingly rare survivors ${ }^{28}$. On the other hand, tachycardias can be treated effectively in utero and have a much more favorable outcome.

Fetuses with thickned nuchal translucency detected by the first trimester screening

Nuchal translucency screening has been shown to be very effective in identifying fetuses at increased risk for both chromosomal anomalies and cardiac malformation. Three to five percent of tested fetuses will be defined as being at high risk for congenital heart disease following nuchal translucency examination. This creates a new population of considerable size that would be candidates for complete fetal echocardiography ${ }^{30}$. A meta-analysis of studies examining the screening performance of NT thickness for the detection of cardiac defects in fetuses with normal karyotype, reported that the detection rates were about $37 \%$ and $31 \%$ for the respective NT cutoffs of the 95th and 99th centiles ${ }^{31}$. This compares favorably with the $10 \%$ detection rate achieved by confining specialist fetal echocardiography to pregnancies with a maternal history of diabetes mellitus or dijagnostike tipa aritmije, već i zbog isključenja srčane anomalije koja može biti prisutna u $30-50 \%$ slučajeva sa kompletnim atrioventrikularnim blokom i u $2-5 \%$ slučajeva sa ekstrasistolama i tahiaritmijama ${ }^{2}$. Najčešći tip fetalnih aritmija je prematurna pretkomorska i komorska kontrakcija, ali je ona od malog kliničkog značaja i nije povezana sa povećanim rizikom strukturnih srčanih anomalija. Iako su tahikardije često uzrok zastoja srčanog rada in utero, one su retko povezane sa strukturnim anomalijama. Suprotno tome, 50\% fetusa sa kompletnim atrioventrikularnim blokom imaju srčane malformacije, a najčešće se radi o atrioventrikularnim septalnim defektima ili korigovanom transpozicijom velikih arterija ${ }^{27}$.

Neimuni fetalni hidrops

Postojanje neimunog fetalnog hidropsa predstavlja indikaciju za fetalnu ehokardiografiju. Nekad je posledica strukturne srčane bolesti, dok je nekad rezultat fetalne aritmije ${ }^{28}$. Neimuni fetalni hidrops je posledica srčanih abnormalnosti u oko $25 \%$ slučajeva ${ }^{29}$. Od toga su dve trećine rezultat aritmija, dok je u trećini posledica strukturnog srčanog defekta. Ponekad fetus može imati i aritmiju i KSB, kao što je to slučaj sa atrioventrikularnim septalnim defektom sa srčanim blokom, ili slučaj Ebštajnove anomalije sa pretkomornim flaterom. Aritmije fetusa mogu biti tahiaritmije, kao što je supraventrikularna tahikardija ili atrijalni flater, ili bradiaritmije, kao što je srčani blok. Strukturne anomalije srca koje su najčešće prisutne u fetalnog hidropsa su : 1) insuficijencija zalistaka, naročito Ebštajnova anomalija, kao i druge abnormalnosti trikuspidnih zalistaka, ali i Sindrom odsutnog pulmonarnog zalistka i atrioventrikularni septalni defekti, i 2) obstrukcije izlaznih komornih traktova, naročito sindrom hipoplastičnog desnog ili levog srca, kada su povezane sa insuficijencijom trikuspidne valvule. Ukoliko je fetalni hidrops praćen bilo aritmijom, bilo strukturnim srčanim defektima, prognoza je veoma loša. Naročito su strukturni srčani defekti i kompletan srčani blok znaci zlokobne prognoze ukoliko je prisutan hidrops, a preživljavanje je izuzetno retko (28). Sa druge strane, tahikardije se efikasno leče in utero i imaju znatno bolji ishod.

Fetusi sa zadebljanom nuhalnom translucencom detektovanom skriningom prvog trimestra

Skrining merenjem nuhalne translucence se pokazao efikasnim u otkrivanju fetusa sa povećanim rizikom za hromozomske anomalije i srčane 
exposure to teratogens and family history of cardiac defects. Abnormalities of the heart and great arteries are the most common congenital defects, and they account for about $20 \%$ of all stillbirths and $30 \%$ of neonatal deaths due to congenital defects ${ }^{32}$. The extent to which fetal NT becomes widely adopted as a method of screening for cardiac defects will depend mainly on the availability of specialist fetal echocardiography. The clinically relevant question at present is to define the patient-specific risk for major cardiac defects based on the measurement of fetal NT, because this will determine the need for specialist fetal echocardiography in the management of the individual patient. malformacije. Ovim pregledom će tri do pet procenata fetusa biti proglašeno za one sa visokim rizikom kongenitalne srčane bolesti. Tako je stvorena značajna populacija fetusa kandidata za kompletnu fetalnu ehokardiografiju ${ }^{30}$. Meta-analiza studija koje su istraživale performanse merenja vratnog zadebljanja kao skrining testa za detekciju KSB u fetusa sa normalnim kariotipom, pokazala je da su stope detekcije bile oko $37 \%$ i $31 \%$ u odnosu na NT cutoff vrednosti 95. i 99. centila ${ }^{31}$. Ovo je mnogo bolje od stope detekcije od $10 \%$ postignute fetalnom ehokardiografijom trudnica sa dijabetes melitusom, onih izloženih dejstvu teratogena i onih sa KSB u porodičnoj anamnezi. Anomalije srca i velikih krvnih sudova su najčešći kongenitalni defekti. One su prisutne u $20 \%$ mrtvorođene dece i u $30 \%$ neonatusa umrlih usled kongenitalnih anomalija ${ }^{32}$. Da li će merenje NT-a biti široko prihvaćen metod skrininga KSB zavisiće prvenstveno od dostupnosti specijalista za fetalnu ehokardiografiju. U ovom momentu je od kliničkog i naučnog značaja da se definiše pacijent specifičan rizik za velike srčane defekte baziran na merenju fetalnog NT-a, jer će to determinisati potrebu za fetalnom ehokardiografijom u menađžmentu individualnog pacijenta.

\section{References}

1. Allan LD. Fetal cardiology. Ultrasound Obstet Gynecol 1994; 4: 441-444.

2. Gembruch U, Geipel A. Indications for fetal echocardiography: Screening for congenital heart disease in low- and high-risk populations. In: Yagel S, Silverman NH, Gembruch U (eds.). Fetal Cardiology. Martin Dunitz Taylor and Francis Group, London and New York 2003; 89-106.

3. Nora JJ. Causes of congenital heart disease: old and new models, mechanisms, and models. Am Heart J 1993; 125: 1409-1419.

4. Ott WJ. The accuracy of antenatal echocardiography screening in high- and low-risk patients. Am J Obstet Gynecol 1995; 172: 1741-1749.

5. Murphy EA, Pyeritz RE. Assessment of genetic risk in congenital heart disease. J Am Coll Cardiol 1991;18(2):311-342.

6. Nora JJ. Causes of congenital heart disease: old and new modes, mechanisms, and models. Am Heart J 1993;125(5 Pt 1):1409-1419.

7. Loser H, Pfefferkorn JR, Themann H. [Alcohol in pregnancy and fetal heart damage]. Klin Padiatr 1992;204(5):335-9.

8. Sandor GC, Smith DF, MacLeod PM. Cardiac malformations in the fetal alcohol syndrome. J Pediatr 1981;98:771-773.

9. Copel JA, Pilu G, Kleinman CS. Congenital heart disease and extracardiac anomalies: associations and indications for fetal echocardiography. Am J Obstet Gynecol 1986;154(5):1121-32.

10. Briggs GG, Freeman RK, Yaffe SJ. Drugs in pregnancy and lactation. 4th ed. Baltimore: Williams \& Wilkins; 1994.

11. Friedman JM, Polifka JE. Teratogenic effects of drugs. A resource for clinicians. Baltimore \& London: The Johns Hopkins University Press; 1994. 
12. Cohen LS, Friedman JM, Jefferson JW, Johnson EM, Weiner ML. A reevaluation of risk of in utero exposure to lithium. JAMA 1994;271(2):146-150.

13. Jacobson SJ, Jones K, Johnson K, Ceolin L, Kaur P, Sahn D, et al. Prospective multicentre study of pregnancy outcome after lithium exposure during first trimester. Lancet 1992;339(8792):530-3.

14. Takatsuki H, Abe Y, Goto T. Two cases of acute promyelocytic leukemia Mi pregnancy and the effect on anthracyclines of fetal development. Jap J Clin Hematol 1992;33(11):1736-1740.

15. Rizzo G, Arduini D, Romanini C. Accelerated cardiac growth and abnormal cardiac flow in fetuses of type I diabetic mothers. Obstet Gynecol 1992;80(3 Pt 1):369-76.

16. Weber HS, Copel JA, Reece EA, Green J, Kleinman CS. Cardiac growth in fetuses of diabetic mothers with good metabolic control. J Pediatr 1991;118(1):103-7.

17. Olah KS, Gee H. Antibody mediated complete congenital heart block in the fetus. Pacing Clin Electrophysiol 1993;16(9):1872-9.

18. Julkunen H, Kaaja R, Wallgren E, Teramo K. Isolated congenital heart block: fetal and infant outcome and familial incidence of heart block. Obstet Gynecol 1993;82::11-16.

19. Platt LD, Koch R, Azen C. Maternal phenylketonuria collaborative study, obstetric aspects and outcome: the first 6 years. Am J Obstet Gynecol 1992;166:1150-1162.

20. Jordan EK, Sever JL. Fetal damage caused by parvoviral infections. Reprod Toxicol 1994;8(2):161-189.

21. Morey AL, Keeling JW, Porter HJ, Fleming KA. Clinical and histopathological features of parvovirus B19 infection in the human fetus. Br J Obstet Gynaecol 1992;99:566-574.

22. Hyett JA, Moscoso G, Papapanagiotou G, Perdu M, Nicolaides KH. Abnormalities of the heart and great arteries in chromosomally normal fetuses with increased nuchal translucency thickness at 11-13 weeks of gestation. Ultrasound Obstet Gynecol 1996;7(4):245-250.

23. Bronshtein M, Egenburg S, Auslander R, Zimmer EZ. Atrioventricular septal defect in a fetus: a false negative diagnosis in early pregnancy. Ultrasound Obstet Gynecol 2000;16(1):98-9.

24. Satomi G, Momoi N, Kikuchi N, Nakazawa M, Momma K. Prenatal diagnosis and outcome of Ebstein's anomaly and tricuspid valve dysplasia in relation to lung hypoplasia. Echocardiography 1994;11(3):215-220.

25. Little J, Bryan E. Congenital anomalies in twins. Sernin Perinatol 1986;10(1):50-64.

26. Schmidt KG, Ulmer HE, Silverman NH, Kleinman CS, Copel JA. Perinatal outcome of fetal complete atrioventricular block: a multicenter experience. J Am Coll Cardiol 1991;17(6):1360-1366.

27. Copel JA, Kleinman CS. The impact of fetal echocardiography on perinatal outcome. Ultrasound Med Biol 1986; 4: 327-335.

28. Poeschmann RP, Verheijen HM, Van Dongen PWJ. Differential diagnosis and causes of nonimmunological hydrops fetalis: a review. Obstet Gynecol Survey 1991;46(4):223-231.

29. Yagel S, Cohen SM, Achiron R. Examination of the fetal heart by five shortaxis views: a proposed screening method for comprehensive cardiac evaluation. Ultrasound Obstet Gynecol 2001; 17: 367-369.

30. Makrydimas G, Sotiriadis A, Ioannidis JP. Screening performance of first-trimester nuchal translucency for major cardiac defects: a meta-analysis. Am J Obstet Gynecol 2003; 189: 1330-1335.

31. Office for National Statistics. Mortality Statistics. Childhood, infancy and perinatal. Series DH3. $2002 ; 35$.

Author for correspondence:

Biljana Arsic, MD, MSc,

Consultant in obstetrics and gynecology

e-mail: arsb@sezampro.rs

Darvinova 25, Beograd 